\title{
Bile acid studies in patients with Crohn's colitis
}

\author{
P. RUTGEERTS, Y. GHOOS, AND G. VANTRAPPEN \\ From the Department of Medical Research, University of Leuven, Leuven, Belgium
}

SUMMARY Bile acid studies were performed in patients with Crohn's disease, radiologically confined to the colon. The bile acid pool size of 10 patients with isolated Crohn's colitis was significantly lower than that of 10 normal control subjects $(P<0.001)$ and of 10 ulcerative colitis patients $(\mathrm{P}<0.005)$. Measurements of ${ }^{14} \mathrm{C}$-excretion in breath and in 24 hours stool collections after the administration of $5 \mu \mathrm{Ci}{ }^{14} \mathrm{C}$-glycocholate showed a normal ${ }^{14} \mathrm{C}$-excretion in breath and usually a markedly increased loss of ${ }^{14} \mathrm{C}$ in the stool ( $>7 \%$ of the dose). The simultaneous administration of $5 \mu \mathrm{Ci}{ }^{3} \mathrm{H}$-polyethylene glycol MW $4000\left({ }^{3} \mathrm{H}-\mathrm{PEG}\right)$ as a marker indicated that the ${ }^{14} \mathrm{C} /{ }^{3} \mathrm{H}$ ratio in the patients with Crohn's colitis was significantly greater than in a control series of patients with diarrhoea not due to bile acid malabsorption. Studies on the composition of duodenal bile showed a significantly decreased concentration of deoxycholic acid in duodenal bile. These observations suggest bile acid malabsorption in patients with Crohn's disease apparently confined to the colon.

In a previous study we showed that the bile acid pool is lowered in patients with uncomplicated Crohn's ileitis (Vantrappen et al., 1977). The decrease of the bile acid pool size was not related to the extent of the radiologically demonstrable lesions, but correlated well with the activity of the disease. Because two patients with very limited ileal disease had a low bile acid pool, investigations were carried out to test the hypothesis that patients with isolated Crohn's colitis, not affecting the ileum at radiological examination, may have a lowered bile acid pool.

\section{Methods}

\section{PATIENTS}

Ten patients were studied, two males and eight females, aged 17 to 46 years (mean age 27 years) (Table 1). All patients had inflammatory lesions which at radiological examination of small and large bowel were confined to the colon. All patients were examined radiologically by careful barium meal alimentation, including study of the terminal ileum under dosed compression. A barium enema with retrograde visualisation of the terminal ileum was also performed in all patients. The radiographs were evaluated by the radiologists and the gastroenterologists separately. The terminal ileum was considered to be normal only if no lesions were detected by both groups of examiners. In seven patients pathological

Received for publication 29 November 1979 proof of Crohn's disease was obtained by rectosigmoidoscopic and/or colonoscopic biopsies. In two of these patients the diagnosis was later confirmed at surgery and on surgical biopsies. In the three other patients the distribution and macroscopic aspect of the lesions at radiological examination and colonoscopy were highly suggestive of Crohn's disease. The rectum of these three patients was unaffected but two patients had typical anal lesions. None of the patients had previously undergone bowel surgery. All patients had a radiologically normal gallbladder. The activity of the disease was evaluated by means of the Crohn's disease activity index (CDAI) proposed by the American National Cooperative Crohn's disease study group (Best et al., 1976). This activity index is obtained by summarising the scores of three clinical and five objectively measurable features of the patient's disease. An index of 150 and lower is associated with inactive disease. Values between 150 and 450 are found with active disease. An index above 450 occurs in patients with fulminating disease. The index was determined during the one week hospitalisation period preceding the bile acid pool measurement. The bile acid pool size of the Crohn's patients was compared with that of two control groups - that is, 10 normal subjects (six males and four females, aged 19 to 63 years, mean age 35 years) and 10 patients with ulcerative colitis (six males and four females, aged 26 to 58 years, mean age 34 years). Two patients with ulcerative colitis had a disease activity index, calculated in the same way as in Crohn 
patients, of less than 150 , six had an index between 150 and 450, and the index was above 450 in two.

When it had been established that the bile acid pool size was decreased in patients with Crohn's colitis additional investigations were carried out. These investigations included measurements of ${ }^{14} \mathrm{C}$. excretion in breath and in 24 hour stool collections after administration of ${ }^{14} \mathrm{C}$-glycocholate, determination of intestinal transit times by means of ${ }^{3} \mathrm{H}$ polyethylene glycol $\left({ }^{3} \mathrm{H}\right.$ PEG), and analysis of duodenal bile composition. All these investigations were carried out within three weeks. Seven of the 10 patients with Crohn's colitis were available for study. The control groups for these investigations consisted of 14 healthy subjects (seven males and eight females, aged 23 to 64 years, mean age 42 years), 12 patients with diarrhoea not due to bile acid malabsorption (six males and six females, aged 25 to 57 years, mean age 43 years), seven patients with documented bile acid diarrhoea (five males and two females, aged 17 to 39 years, mean age 29 years), and seven patients with ulcerative colitis (four males and three females, aged 21 to 68 years, mean age 46 years).

\section{MATERIALS}

${ }^{14} \mathrm{C}$-glycocholic acid, sodium salt, and ${ }^{14} \mathrm{C}$-cholic acid, were purchased from the Radiochemical Centre (Amersham, Eng.). The chemical purity of both products was checked by thin-layer chromatography on silica gel G-plates (Merck, Germany) in the solvent system propionic acid/isoamylacetate/propanol/water (15: $20: 10: 5)$ (Hofmann, 1962). The radiopurity was evaluated by radioscanning (Berthold, model LB 2723, Erlangen, Germany) and was found to be greater than $99 \%$ for both products. Polyethylene glycol $\left(1,2-{ }^{3} \mathrm{H}\right)\left({ }^{3} \mathrm{H}-\mathrm{PEG}\right) \mathrm{Mw} 4000$ was obtained from New England Nuclear (Boston, Mass., USA), and was used without further purification. All radioactivity measurements were made with a liquid scintillation counter (Packard, model 2450; Downers Grove, Ill., USA). Quenching was corrected by external standardisation. The enzyme used for bile acid assays (3-alfahydroxysteroiddehydrogenase) was obtained from Worthington (Freehold, USA).

\section{ASSAYS}

Total bile acids were determined enzymatically according to the method of Koss et al. (1975). For qualitative analyses the bile acids were converted to their methylesteracetates and assayed gas-chromatographically on $3 \% \mathrm{OV}-1$ or $3 \% \mathrm{OV}-17$ columns in a Pye Unicam gas chromatograph, model 104. Bile acids were extracted from fresh bile on an Amberlite XAD-2 column, as described by Schwarz et al. (1974). Taurine and glycine conjugates, and total unconjugated bile acids were separated by thin-layer chromatography on silica gel G-plates (Merck, Darmstadt, Germany) in the solvent propionic acid/ isoamylacetate/propanol/water $(15: 20: 10: 5)$ (Hofmann, 1962). Results were statistically evaluated using Student's $t$ test, and standard correlation techniques. Data are expressed as mean values \pm standard errors of the mean.

\section{POOL SIZE MEASUREMENT}

The pool size was measured by the single intubation and sampling technique (Pomare and Low-Beer, 1974). A radio-opaque catheter was positioned in the duodenum of the patients in the fasting state. $5 \mu \mathrm{Ci}\left({ }^{14} \mathrm{C}\right)$-cholic acid was injected intravenously. After a period of three hours, the gallbladder was stimulated by intravenous administration of pan-

Table 1 Clinical and laboratory data in patients with Crohn's colitis

\begin{tabular}{|c|c|c|c|c|c|c|c|c|c|c|c|}
\hline Patien & $\begin{array}{l}\text { Age } \\
(y r)\end{array}$ & $\operatorname{Sex}$ & $\begin{array}{l}\text { Lesions } \\
(P+=\text { typical pathol. })\end{array}$ & $\begin{array}{l}\text { Leucocyte } \\
\text { count } \\
\left(10^{\circ} / D\right)\end{array}$ & $\begin{array}{l}\text { Sed. } \\
\text { rate } \\
(\mathrm{mm} / \mathrm{h})\end{array}$ & $\begin{array}{l}\text { Ser. } \\
\text { alb. } \\
(g / l)\end{array}$ & $\begin{array}{l}\text { Ser. } \\
\mathrm{Ca} \\
(\mathrm{mmol} / \mathrm{l})\end{array}$ & $\begin{array}{l}\text { Ser. } \\
\text { carotene } \\
(\mu \mathrm{mol} / \mathrm{l})\end{array}$ & $\begin{array}{l}\text { Cholest. } \\
(\mathrm{mmol} / \mathrm{l})\end{array}$ & $\begin{array}{l}\text { Schill. } \\
\text { test } \\
{ }^{57} \mathrm{Co}-\% \\
\text { excret. } / 24 \mathrm{~h}\end{array}$ & $C D A I^{*}$ \\
\hline D.S. & 21 & $\mathbf{M}$ & $\begin{array}{l}\text { Entire colon }(P+) \dagger \text { recto- } \\
\text { vesical fistula }\end{array}$ & $7 \cdot 1$ & 29 & $30 \cdot 0$ & $2 \cdot 28$ & $1 \cdot 3$ & $3 \cdot 21$ & - & 206 \\
\hline S.F. & 22 & $\mathbf{F}$ & $\begin{array}{l}\text { Segmental lesions, right } \\
\text { colon, anus }\end{array}$ & $3 \cdot 5$ & 7 & $24 \cdot 0$ & $2 \cdot 01$ & 0.7 & $3 \cdot 70$ & $10 \cdot 7$ & 551 \\
\hline P.A. & 46 & $\mathbf{M}$ & $\begin{array}{l}\text { Left colon } \dagger \text { pericolic } \\
\text { abscess }\end{array}$ & $8 \cdot 0$ & 65 & $34 \cdot 9$ & $2 \cdot 28$ & $1 \cdot 8$ & $5 \cdot 28$ & - & 235 \\
\hline V.M. & 17 & $\mathbf{F}$ & Left colon-caecumt-anus & $4 \cdot 4$ & 16 & $34 \cdot 6$ & $2 \cdot 25$ & $1 \cdot 1$ & $4 \cdot 20$ & $6 \cdot 3$ & 410 \\
\hline D.C. & 37 & $\mathbf{F}$ & Rectum, anus $\dagger$ & $8 \cdot 3$ & 5 & $38 \cdot 9$ & $2 \cdot 53$ & $4 \cdot 3$ & 6.53 & $20 \cdot 0$ & 42 \\
\hline B.M. & 31 & $\mathbf{F}$ & Segmental lesions anus & $8 \cdot 6$ & 22 & $39 \cdot 1$ & $2 \cdot 53$ & 3.9 & $6 \cdot 14$ & $22 \cdot 0$ & 121 \\
\hline G.J. & 28 & $\mathbf{F}$ & Entire colont anus & 6.9 & 85 & 19.9 & $2 \cdot 18$ & $1 \cdot 1$ & $4 \cdot 61$ & $8 \cdot 1$ & 344 \\
\hline Z.M. & 17 & $\mathbf{F}$ & Entire colon rectum: normal & $21 \cdot 1$ & 13 & $17 \cdot 9$ & $2 \cdot 03$ & $0 \cdot 8$ & $1 \cdot 89$ & $18 \cdot 0$ & 452 \\
\hline B.L. & 26 & $\mathbf{F}$ & Entire colon and rectum $\dagger$ & $12 \cdot 2$ & 120 & $29 \cdot 4$ & $2 \cdot 40$ & 0.9 & $5 \cdot 15$ & $10 \cdot 4$ & 321 \\
\hline $\begin{array}{l}\text { F.A. } \\
\text { Normal }\end{array}$ & $\begin{array}{l}29 \\
\text { values }\end{array}$ & $\mathbf{F}$ & Entire colon and rectum $†$ & $\begin{array}{r}10.4 \\
<10.0\end{array}$ & $\begin{array}{r}25 \\
<12\end{array}$ & $\begin{array}{l}34 \cdot 6 \\
38 \cdot 5-47 \cdot 5\end{array}$ & $\begin{array}{l}2 \cdot 33 \\
2 \cdot 2-2 \cdot 6\end{array}$ & $\begin{array}{l}1.0 \\
0.9-3.7\end{array}$ & $\begin{array}{l}3 \cdot 26 \\
3.9-5.2\end{array}$ & $-8.0 \%$ & 243 \\
\hline Normal & values & & & $<10.0$ & $<12$ & $38 \cdot 5-47 \cdot 5$ & $2 \cdot 2-2 \cdot 6$ & $0 \cdot 9-3 \cdot 7$ & $3 \cdot 9-5 \cdot 2$ & $>8.0 \%$ & \\
\hline
\end{tabular}

*Crohn's Disease Activity Index.

†Pathological proof. 
creozymin (1 Boots unit/kg body weight) (Boots Comp., Nottingham, Eng.). Duodenal fluid was aspirated for $\mathbf{4 0}$ minutes and thoroughly mixed. The total volume was registered, $10 \mathrm{ml}$ was kept for analysis and the remainder was reinstilled into the duodenum. The cholic ${ }^{14} \mathrm{C}$-activity dilution is measured versus the amount of total bile acids.

\section{BREATH TEST}

The bile acid breath test was performed according to the method of Fromm and Hofmann (1971) with slight modifications. After an overnight fast, subjects and patients took with their breakfast a starch capsule containing $5 \mu \mathrm{Ci}{ }^{14} \mathrm{C}$-glycocholic acid. Breath samples were collected before and 1, 2, 3, 4, 5, 6, 8, 10,12 , and 24 hours after breakfast and the radioactivity of the $2 \mathrm{mmol} \mathrm{CO}_{2}$, trapped in a 4-ml hyamine hydroxide solution, $0.5 \mathrm{M}$, was measured.

\section{STOOL MEASUREMENTS}

Concomitantly with the capsule containing $5 \mu \mathrm{Ci}$ ${ }^{14} \mathrm{C}$-glycocholic acid, another capsule containing $5 \mu \mathrm{Ci}{ }^{3} \mathrm{H}-\mathrm{PEG}$ as an intestinal transit marker was administered to the control subjects and to seven of 10 patients with Crohn's colitis. Control subjects and patients defaecated into a deep-freeze toilet for 24 hours after the ingestion of the capsules. The 24 hour stool collections were collected and analysed as described elsewhere (Ghoos and Vantrappen,

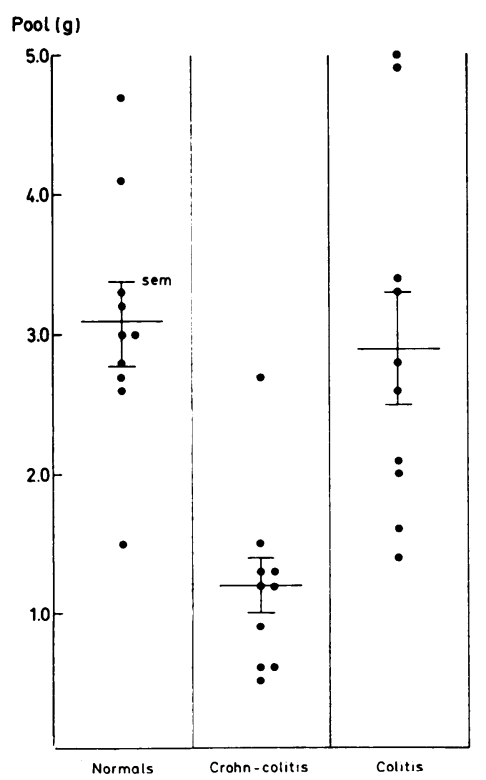

Fig. 1 Bile acid pool size in patients with isolated Crohn's colitis, patients with ulcerative colitis, and in normal subjects.

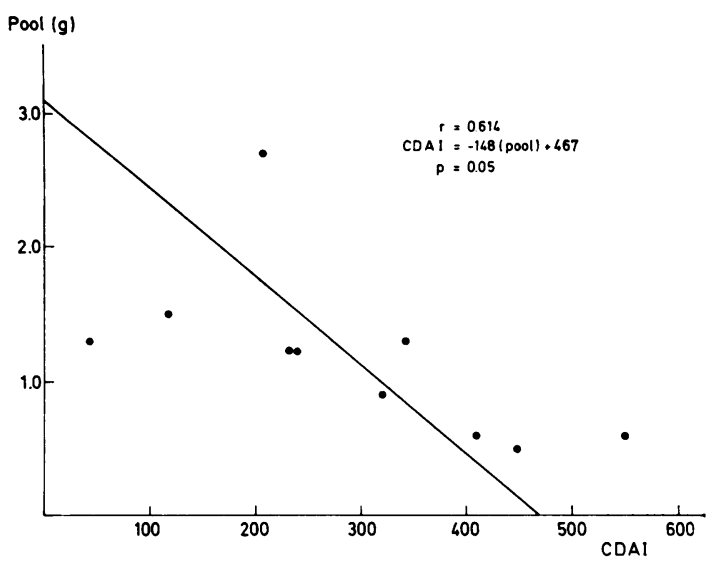

Fig. 2 Crohn's disease activity index (CDAI) and bile acid pool size in patients with Crohn's colitis.

1977). An aliqout of the three day stool was analysed for fat content according to the method of Jeejeehboy (1970). ${ }^{14} \mathrm{C}$ - and ${ }^{3} \mathrm{H}$ - measurements of the stool were carried out after oxidation (Packard, model 306) of a lyophilised sample of faeces. In order to determine the effect of diarrhoea, not due to bile acid malabsorption, on the excretion of the labelled glycine in the stool, the ${ }^{14} \mathrm{C} /{ }^{3} \mathrm{H}$ PEG ratio was determined. (Fromm et al., 1973).

VITAMIN B-12 ABSORPTION

The Schilling test with vitamin $\mathrm{B} 12-{ }^{57} \mathrm{Co}$ and intrinsic factor was performed in the seven patients in whom faecal analysis was carried out.

\section{Results}

BILE ACID POOL SIZE

The mean bile acid pool size in the 10 patients with Crohn's colitis was $1 \cdot 18 \mathrm{~g} \pm \mathbf{0} \cdot 20$. This is significantly lower than the bile acid pool size of the 10 patients with ulcerative colitis $(2.9 \mathrm{~g} \pm 0.40 \mathrm{~g}$; $\mathrm{P}<0.005)$ and of the 10 normal subjects $(3.1 \mathrm{~g} \pm$ $0.27 \mathrm{~g} ; \mathrm{P}<0.001$ ). Only one patient with Crohn's colitis had a bile acid pool size well within the limits of the control group (Fig. 1). Crohn's disease was inactive in two patients $(<150)$, active in six patients $(150>$ CDAI $<450)$ and fulminating in two patients (CDAI $>450)$. The correlation between the activity of the disease and the decrease of the bile acid pool size is shown in Fig. 2.

COMPOSITION OF DUODENAL BILE (Table 2) The glyco/tauro ratio in duodenal bile of the Crohn's colitis patients was $4 \cdot 81 \pm 1 \cdot 56$ as against $2 \cdot 35 \pm 0 \cdot 17$ for normal subjects. This difference is not significant. $5.04 \% \pm 1.89 \%$ of the bile acids in the duodenal bile 
Table 2 Size and composition of bile acid pool of patients with Crohn's colitis

\begin{tabular}{|c|c|c|c|c|c|c|c|c|c|}
\hline Patients & $\begin{array}{l}\text { BA } \\
\text { pool size } \\
(g)\end{array}$ & $\begin{array}{l}\text { Breath test } \\
\text { (cumul. } 12 \text { h) }\end{array}$ & $G / T$ & Free & $L C$ & $D C$ & $C D C$ & $U C$ & $C$ \\
\hline $\begin{array}{l}\text { D.S. } \\
\text { S.F. } \\
\text { P.A. } \\
\text { V.M. } \\
\text { D.C. } \\
\text { B.M. } \\
\text { G.J. } \\
\text { Z.M. } \\
\text { B.L. } \\
\text { F.A. } \\
\text { Mean } \\
\text { SEM }\end{array}$ & $\begin{array}{l}2.7 \\
0.6 \\
1 \cdot 2 \\
0.6 \\
1 \cdot 3 \\
1.5 \\
1.3 \\
0.5 \\
0.9 \\
1 \cdot 2 \\
1 \cdot 18 \\
0.20\end{array}$ & $\begin{array}{l}2 \cdot 1 \\
8 \cdot 6 \\
1 \cdot 7 \\
3 \cdot 0 \\
9 \cdot 4 \\
1 \cdot 6 \\
8.9 \\
2 \cdot 1 \\
5.9 \\
1 \cdot 8 \\
4 \cdot 51 \\
1.05\end{array}$ & $\begin{array}{r}3.8 \\
15 \cdot 7 \\
1.6 \\
2.0 \\
2.2 \\
0.7 \\
11.1 \\
6.6 \\
1.7 \\
2.7 \\
4.81 \\
1.56\end{array}$ & $\begin{array}{c}0 \\
0 \\
9 \\
8 \\
0 \\
0 \\
0 \\
8 \\
17 \cdot 4 \\
8 \\
5 \cdot 04 \\
1.89\end{array}$ & $\begin{array}{l}2 \\
0 \\
1.6 \\
1.6 \\
0 \\
0 \\
0 \\
0 \\
0 \\
0 \\
0.52 \\
0.27\end{array}$ & $\begin{array}{c}16 \\
0.8 \\
23 \\
6 \\
2 \\
2 \\
3 \\
1 \\
0 \\
2 \\
5 \cdot 58 \\
2.43\end{array}$ & $\begin{array}{l}50 \\
64 \\
40 \\
60 \\
63 \\
48 \\
22 \\
27 \\
48 \\
45 \\
46 \cdot 70 \\
4.47\end{array}$ & $\begin{array}{l}0 \\
5 \cdot 3 \\
3 \\
1 \cdot 3 \\
0 \\
0 \\
0 \\
0 \\
0 \\
0 \\
0.96 \\
0 \cdot 57\end{array}$ & $\begin{array}{l}33 \\
30 \\
32 \\
31 \\
35 \\
50 \\
75 \\
72 \\
32 \\
53 \\
44 \cdot 30 \\
5.49\end{array}$ \\
\hline
\end{tabular}

BA: bile acid. G/T: ratio of glyco/tauro conjugates. Free: free bile acids. LC: lithocholic acid. DC: deoxycholic acid. CDC: chenodeoxycholic acid. UC: ursodeoxycholic acid. C: cholic acid. Bile acids are expressed as a per cent of total bile acid amount. Breath test: the figures represent the cumulative $12 \mathrm{~h}$ excretion in the breath, expressed as a percentage of the administered dose (upper limit: 10.0\%).

were not conjugated. Five of the 10 patients with Crohn's colitis did not have free bile acids in their bile. Deoxycholic acid constituted $5 \cdot 58 \% \pm 2.43 \%$ of the bile acids in patients with Crohn's colitis, which was significantly lower $(0.01>P>0.005)$ than the concentration in normal subjects $(15.27 \% \pm$ $2.05 \%)$. There was no significant difference between the deoxycholic acid content in patients with Crohn's colitis and in patients with ulcerative colitis $(9.03 \%$ $\pm 2.64 \%)(0.3<\mathrm{P}<0.4)$.

\section{BREATH TESTS AND STOOL ANALYSES}

The mean excretion of ${ }^{14} \mathrm{CO}_{2}$ in the breath during the 12 hours after the administration of $5 \mu \mathrm{Ci}$ glycocholic acid was $4.51 \%$ in the patients with Crohn's colitis and $5.90 \%$ in the control group. The upper limit for ${ }^{14} \mathrm{CO}_{2}$ excretion in the breath in the latter group is $10.0 \%$.

The excretion ratios of ${ }^{14} \mathrm{C}$ on the 24 hour stool collections after the administration of ${ }^{14} \mathrm{C}$-glycocholic acid are summarised in Table 3. Normal subjects excreted a mean of $1.04 \%$ of the dose (range $0.02 \%-5.02 \%$. The mean faecal excretion of ${ }^{14} \mathrm{C}$ in the seven patients with Crohn's colitis was $9.4 \%$ of the dose (range $1.40 \%-26.2 \%$ ), which is significantly larger than in the control group subjects $(0.001<$ $\mathrm{P}<0.005$ ). Five of the seven patients had ${ }^{14} \mathrm{C}$-stool excretion of more than $5.02 \%$ of the dose. In these five patients the ${ }^{14} \mathrm{C} /{ }^{3} \mathrm{H}$ ratio was calculated. Figure 3 illustrates the ${ }^{14} \mathrm{C} /{ }^{3} \mathrm{H}$ ratios in the 24 hour stool collections of the five patients with Crohn's colitis and diarrhoea, seven patients with documented bile acid diarrhoea, and 11 patients with diarrhoea not due to bile acid malabsorption. In patients with diarrhoea not associated with bile acid malabsorption the ratio was $0.08 \pm 0.02$. In contrast, significantly greater ratios were found in patients with ileal dysfunction $(0.50 \pm 0.04 ; \mathrm{P}<0.001)$ and in patients with 'isolated' Crohn's colitis (0.51 \pm 0.14 ;
$\mathrm{P}<0.001)$. The ${ }^{14} \mathrm{C} /{ }^{3} \mathrm{H}$ ratio of the colitis patients was not different from that of the patients with documented ileal dysfunction. Six of the seven patients with Crohn's colitis had diarrhoea with a stool weight of more than $200 \mathrm{~g} / 24$ hours. The faecal fat excretion was normal in all seven Crohn's colitis patients in whom it was determined. The upper limit of faecal fat excretion was taken at $7 \mathrm{~g}$ /day.

\section{VITAMIN B 12 ABSORPTION}

The Schilling test was normal in five patients, borderline in one patient, and severely disturbed in one patient.

\section{Discussion}

These observations indicate that the bile acid pool size of patients suffering from Crohn's disease,

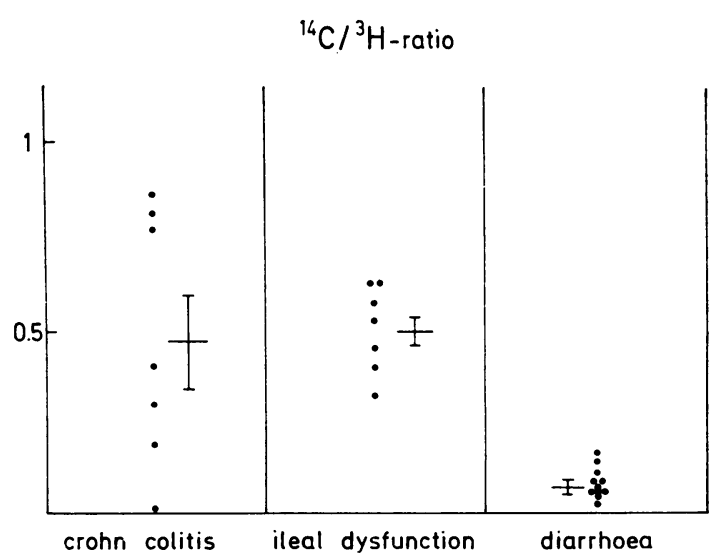

Fig. $3{ }^{14} \mathrm{C} /{ }^{3} \mathrm{H}$ ratio in the stool of patients with Crohn's colitis, patients with ileal dysfunction, and patients with diarrhoea, not due to bile acid malabsorption. 
radiologicany confined to the colon, is significantly lower than the bile acid pool size of patients with ulcerative colitis and of normal subjects. The male/ female ratio in the control group is larger than in the group of patients. Small differences in bile acid synthesis between men and women have been reported (Einarsson et al., 1974), but these differences cannot account for the marked differences in pool size between the patients and the control group. The pathogenesis of this decrease in bile acid pool size was studied by measuring the ${ }^{14} \mathrm{C}$-activity loss in the stool after the administration of ${ }^{14} \mathrm{C}$-glycocholic acid. The mean ${ }^{14} \mathrm{C}$-faecal loss was found to be increased

Table 3 Faecal mass, faecal fat and the ${ }^{14} \mathrm{C}$ - and ${ }^{3} \mathrm{H}$ - content of 24 hour stool of normal subjects, patients with Crohn's colitis, patients with ileal dysfunction, and patients with diarrhoea not due to bile acid malabsorption

\begin{tabular}{|c|c|c|c|c|c|}
\hline Patients & $\begin{array}{l}\text { Faeces } \\
(\mathrm{g} / 24 \mathrm{~h})\end{array}$ & $\begin{array}{l}{ }^{14} C^{*} \\
(\%)\end{array}$ & $\begin{array}{l}{ }^{3} H^{*} \\
(\%)\end{array}$ & $\begin{array}{l}{ }^{14} \mathrm{C} /{ }^{3} \mathrm{H}- \\
\text { ratio }\end{array}$ & $\begin{array}{l}\text { Faecal fat } \\
(\mathrm{g} / \text { day })\end{array}$ \\
\hline \multicolumn{6}{|c|}{ Normal subjects } \\
\hline V.D.H. & 82 & 0.02 & 0.84 & - & - \\
\hline B.M. & 200 & 1.83 & $28 \cdot 4$ & - & - \\
\hline P.C. & 104 & 0.02 & 0.8 & - & 一 \\
\hline S.I. & 191 & 0.7 & $9 \cdot 4$ & - & - \\
\hline V.J. & 194 & $1 \cdot 6$ & $23 \cdot 5$ & - & - \\
\hline V.H. & 81 & 0.8 & $23 \cdot 6$ & - & - \\
\hline V.D.V. & 175 & 0.41 & $23 \cdot 4$ & - & - \\
\hline R.J. & 59 & 0.03 & $8 \cdot 89$ & - & - \\
\hline D.A. & 203 & $5 \cdot 02$ & $65 \cdot 8$ & - & - \\
\hline V.D.K. & 156 & $0 \cdot 15$ & 0.7 & - & - \\
\hline V.L.G. & 136 & 0.42 & $23 \cdot 52$ & - & - \\
\hline V.D.L. & 156 & $3 \cdot 2$ & $52 \cdot 0$ & 一 & - \\
\hline V.S. & 41 & 0.02 & $17 \cdot 0$ & - & - \\
\hline A.E. & 135 & 0.4 & $14 \cdot 3$ & - & - \\
\hline \multicolumn{6}{|c|}{ Patients with Crohn's colitis } \\
\hline S.F. & 29 & $3 \cdot 1$ & 3.96 & $0 \cdot 78$ & 0.4 \\
\hline V.M. & 216 & $9 \cdot 8$ & $11 \cdot 4$ & 0.86 & $1 \cdot 2$ \\
\hline D.C. & 716 & $10 \cdot 2$ & $12 \cdot 6$ & 0.81 & 5.0 \\
\hline B.M. & 675 & $7 \cdot 5$ & $18 \cdot 1$ & 0.40 & $3 \cdot 2$ \\
\hline G.J. & 1698 & $8 \cdot 0$ & $42 \cdot 0$ & $0 \cdot 19$ & 6.0 \\
\hline Z.M. & 231 & 1.4 & $33 \cdot 5$ & 0.04 & $2 \cdot 5$ \\
\hline B.L. & 467 & $26 \cdot 2$ & $87 \cdot 3$ & $0 \cdot 30$ & $4 \cdot 0$ \\
\hline \multicolumn{6}{|c|}{ Patients with ileal dysfunction } \\
\hline B.J. & 935 & $52 \cdot 1$ & 84.03 & 0.62 & 6.8 \\
\hline D.E. & 261 & $13 \cdot 7$ & $26 \cdot 35$ & 0.52 & $2 \cdot 1$ \\
\hline D.J. & 366 & $21 \cdot 7$ & $54 \cdot 25$ & 0.40 & $2 \cdot 9$ \\
\hline V.M. & 221 & $25 \cdot 7$ & $80 \cdot 3$ & 0.32 & $2 \cdot 0$ \\
\hline W.M. & 541 & $46 \cdot 3$ & $81 \cdot 23$ & 0.57 & $8 \cdot 2$ \\
\hline J.A. & 320 & $37 \cdot 2$ & $60 \cdot 00$ & 0.62 & $3 \cdot 1$ \\
\hline G.M. & 295 & $33 \cdot 2$ & & 0.45 & $1 \cdot 6$ \\
\hline \multicolumn{6}{|c|}{ Patients with diarrhoea } \\
\hline D.T. & 339 & 0.08 & $1 \cdot 64$ & 0.05 & $8 \cdot 2$ \\
\hline M.M. & 389 & 6.8 & 76.8 & 0.08 & 3.0 \\
\hline S.L. & 363 & $2 \cdot 7$ & $23 \cdot 6$ & $0 \cdot 11$ & $2 \cdot 5$ \\
\hline J.H. & 564 & $1 \cdot 2$ & $61 \cdot 4$ & 0.02 & $4 \cdot 1$ \\
\hline H.M. & 275 & 1.4 & 35.4 & 0.04 & 1.5 \\
\hline V.J. & 445 & $2 \cdot 3$ & 46.5 & 0.05 & $1 \cdot 7$ \\
\hline C.A. & 477 & $3 \cdot 2$ & $68 \cdot 1$ & 0.05 & $5 \cdot 5$ \\
\hline J.L. & 646 & $3 \cdot 8$ & 66.9 & 0.06 & $7 \cdot 3$ \\
\hline L.A. & 226 & 3.4 & $24 \cdot 3$ & $0 \cdot 14$ & $1 \cdot 1$ \\
\hline P.M. & 312 & $4 \cdot 5$ & $56 \cdot 3$ & 0.08 & 3.4 \\
\hline W.M. & 422 & $4 \cdot 6$ & $21 \cdot 9$ & $0 \cdot 21$ & \\
\hline
\end{tabular}

$* \%{ }^{14} \mathrm{C}, \%{ }^{3} \mathrm{H}$ : per cent activity of ingested radioactive tracer, recovered in the stool. in patients with Crohn's colitis. It has been demonstrated that the excretion of ${ }^{14} \mathrm{C}$ in the stool after administration of ${ }^{14} \mathrm{C}$-glycocholate is a good measure of the degree of faecal bile acid loss (Fromm et al., 1973). Scarpello et al. (1977) performed ${ }^{14} \mathrm{C}$-glycocholate breath tests and measured the faecal ${ }^{14} \mathrm{C}$ output in three patients with isolated Crohn's colitis. In one patient faecal ${ }^{14} \mathrm{C}$-excretion was increased and in another it was at the upper limit or normal.

Our observations on the ${ }^{14} \mathrm{C} /{ }^{3} \mathrm{H}$ ratio in the 24 hour stool collection suggest that bile acids are malabsorbed in patients with Crohn's colitis. Fromm et al. (1973) measured the ${ }^{14} \mathrm{C} /{ }^{51} \mathrm{Cr}$ ratio in the stool after administration of ${ }^{14} \mathrm{C}$-glycocholate and ${ }^{51} \mathrm{CrCl}_{3}$. In 22 ileal resection patients they found a ratio of $0.36 \pm 0.04$ (range $0.04-0.82$ ); in seven diarrhoea control subjects with no detectable ileal disease the ratio was considerably lower $(0.09 \pm 0.02$, range $0.01-0 \cdot 22)$. These authors found ${ }^{51} \mathrm{CrCl}_{3}$ to be an imperfect marker, as five of these 22 ileal resection patients excreted the marker more slowly than the labelled bile acid; we therefore used ${ }^{3} \mathrm{H}-\mathrm{PEG}$ as a marker. In none of our ileal dysfunction patients was the ${ }^{3} \mathrm{H}-\mathrm{PEG}$ marker excreted more rapidly than the ${ }^{14} \mathrm{C}$-label. In our patients with diarrhoea not associated with bile acid loss, the ${ }^{14} \mathrm{C} /{ }^{3} \mathrm{H}$ ratio was low $(0.08 \pm 0.02)$. In contrast, the ${ }^{14} \mathrm{C} /{ }^{3} \mathrm{H}$ ratio in our patients with Crohn's disease apparently confined to the colon was as high as in our patients with documented ileal dysfunction. This raised ${ }^{14} \mathrm{C} /{ }^{3} \mathrm{H}$ ratio in the stool indicates that faecal ${ }^{14} \mathrm{C}$-excretion is clearly abnormal in our Crohn colitis patients, although no correlation could be demonstrated between this ratio and the bile acid pool size. Lenz (1976) found that in unoperated patients with severe ulcerative colitis there was an increased excretion of ${ }^{14} \mathrm{C}$ in the faeces after administration of ${ }^{14} \mathrm{C}$-glycocholate and lowered post-prandial duodenal bile acid concentrations. In our group of patients with ulcerative colitis only two patients have severe disease. The pool of these two patients overlapped with the pool of Crohn colitis patients, which could confirm the results of Lenz (1976).

Vitamin B12 absorption, studied by means of the Schilling test, was markedly abnormal in only one patient and borderline in one other patient. It has been stressed by several authors (Fromm et al., 1973; Hepner, 1975; Lenz, 1975; Scarpello et al., 1977) that the Schilling test is a less sensitive parameter of ileal function than the ${ }^{14} \mathrm{C}$-glycocholate breath test, combined with faecal ${ }^{14} \mathrm{C}$-analysis.

The relative concentration of deoxycholic acid in duodenal bile was lower in patients with Crohn's colitis $(5.6 \%)$ than in ulcerative colitis patients $(9.0 \%)$ and significantly lower than in normal subjects $(15 \cdot 3 \%)$. The concentration of cholic acid 
in patients with Crohn's colitis (44.3\%) was higher than in patients with ulcerative colitis $(40.8 \%)$ and controls $(36.9 \%)$. These data show that the formation or conservation of deoxycholic acid is impaired. This may be due to the inability of the colon to absorb deoxycholic acid (Heaton, 1977). The decreased deoxycholic acid concentrations in duodenal bile may also be caused by an interrupted enterohepatic circulation (Thaysen et al., 1970). Most probably, however, the decrease of deoxycholic acid is caused by the short period of time during which the bacteria are exposed to adequate cholic acid concentrations (Kern, 1974). This could also explain the low ${ }^{14} \mathrm{CO}_{2}$-output in the breath, because there is not sufficient time for the hydrolysis of glycocholate.

These three observations-that is, the increased loss of ${ }^{14} \mathrm{C}$ in stool, the increased ${ }^{14} \mathrm{C} /{ }^{3} \mathrm{H}$ ratio in stool, and the decreased relative concentration of deoxycholic acid in bile-are consistent with the view that the low bile acid pool size in patients with isolated Crohn's colitis is due to bile acid loss. Thus, Crohn's colitis seems to be frequently associated with ileal dysfunction, even if the ileum looks normal on careful radiological examination.

We acknowledge the skilful technical assistance of Mrs S. Rutten and Mr L. Verhaegen. This research was sponsored by grants from the Fonds voor Wetenschappelijk Geneeskundig Onderzoek van België; Brussels, Belgium.

\section{References}

Best, W. R., Becktel, J. M., Singleton, J. W., and Kern, F., Jr. (1976). Development of a Crohn's disease activity index-National cooperative Crohn's disease study. Gastroenterology, 70, 439-444.

Einarsson, K., Hellström, K., and Kallner, M. (1974). Bile acid kinetics in relation to sex, serum lipids, body weights and gallbladder disease in patients with various types of hyperlipoproteinemia. Journal of Clinical Investigations, 54, 1301-1311.

Fromm, H., and Hofmann, A. F. (1971). Breath test for altered bile-acid metabolism. Lancet, 2, 621-625.
Fromm, H., Thomas, P. J., and Hofmann, A. F. (1973). Sensitivity and specificity in tests of distal ileal function: prospective comparison of bile acid and vitamin B12 absorption in ileal resection patients. Gastroenterology, 64, 1077-1090.

Ghoos, Y., and Vantrappen, G. (1977). Clean collection and manipulation of stools. Lancet, 1, 884-885.

Heaton, K. W. (1977). Disturbances of bile acids metabolism in intestinal disease. Clinics in Gastroenterology, 6, 69-89.

Hepner, G. (1975). Increased sensitivity of the cholylglycine breath test for detecting ileal dysfunction. Gastroenterology, 68, 8-16.

Hofmann, A. F. (1962). Thin-layer absorption chromatography of free and conjugated bile acids in silicic acid. Journal of Lipid Research, 3, 127-128.

Jeejeehboy, K. N., Ahmad, S., and Kozak, G. (1970). Determination of fecal fats containing both medium and long chain triglycerides and fatty acids. Clinical Biochemistry, 3, 157-163.

Kern, F., Jr. (1974). Disappearance of deoxycholic acid after ileal resection. Gastroenterology, 64, 123-127.

Koss, F., Mayer, D., and Haindl, H. (1965). Methoden der enzymatischen Analyse, pp. 1824-1827. Edited by H. Bergmeyer. Verlag Chemie: Weinheim.

Lenz, K. (1975). An evaluation of the 'breath test' in Crohn's disease. Scandinavian Journal of Gastroenterology, 10, 665-671.

Lenz, K. (1976). Bile acid metabolism and vitamin B12 absorption in ulcerative colitis. Scandinavian Journal of Gastroenterology, 11, 769-775.

Pomare, E. W., and Low-Beer, T. S. (1974). Measurement and validation of human bile salt pool size and synthesis. Clinica Chimica Acta, 57, 239-248.

Scarpello, J. H. B., and Sladen, G. E. (1977). ${ }^{14}$ Cglycocholate test in Crohn's disease-its value in assessment and treatment. Gut, 18, 736-741.

Schwarz, H. P., von Bergmann, K., and Paumgartner, G. (1974). A simple method for the estimation of bile acids in serum. Clinica Chimica Acta, 50, 197-206.

Thaysen, E. H., Bruusgaard, A., and Eriksen, B. (1970). Evaluation of the efficiency of bile salt recirculation in patients with terminal ileopathies by means of deoxycholate determination in duodenal aspirates. Scandinavian Journal of Gastroenterology, 5, 39-47.

Vantrappen, G., Ghoos, Y., Rutgeerts, P., and Janssens, J. (1977). Bile acid studies in uncomplicated Crohn's disease. Gut, 18, 730-735. 